\title{
A comparison of three column agglutination tests for red blood cell alloantibody identification
}

Siska Blomme ${ }^{1 *}$, Emilie De Maertelaere ${ }^{2}$ and Eline Verhoye ${ }^{3}$

\begin{abstract}
Objective: Commercial kits of column tests for pre-transfusion testing have progressively replaced conventional tube tests in most laboratories. Aim of this study was to compare three commercial test cell panels for the identification of irregular red blood cell (RBC) alloantibodies. Overall, 44 samples with a positive indirect antiglobulin test (IAT) by routine testing were used for comparison of following panels: Ortho RESOLVE ${ }^{\circledR}$ panelC (Ortho Clinical Diagnostics (OCD), Milan, Italy), ID-DiaPanel(-P) (Bio-Rad Laboratories, CA, USA) and Identisera Diana(P) (Grifols, Barcelona, Spain). Column agglutination techniques were used, with microtubes containing either microgel (Bio-Rad/Grifols) or glass bead microparticles (Ortho).

Results: Alloantibody identification was possible in 38 samples, of which identical identification was shown in 33 samples by all methods. The remaining samples showed differences between certain methods, with the gel card system being superior to the glass card system for analyzing stored samples Considering that not all samples were evaluated in all three methods, the concordance rate reached 100\% between Bio-Rad and Grifols, 90.5\% between BioRad and OCD, 86.5\% between OCD and Grifols and 90.5\% between all methods. Although differences in sensitivities were seen for specific antibodies, the three methods showed comparable performance for the identification of RBC alloantibodies.
\end{abstract}

Keywords: Column agglutination technique, Red blood cell antibodies, Alloantibody identification, Transfusion medicine, Pre-transfusion testing

\section{Introduction}

The screening and identification of red blood cell (RBC) alloantibodies is performed as pre-transfusion testing (Type and Screen) and in pregnancy to detect potential hemolytic disease of the fetus and newborn (HDFN). A low ionic strength solution (LISS) indirect antiglobulin test (IAT) is considered the most suitable for the detection of clinically significant antibodies because of its speed, sensitivity and specificity $[1,2]$. According to several international guidelines (such as BSH (British

\footnotetext{
*Correspondence: blommesiska@gmail.com

${ }^{1}$ Clinical Department of Laboratory Medicine, University Hospitals, Herestraat, 493000 Leuven, Belgium

Full list of author information is available at the end of the article
}

Society for Haematology) and $\mathrm{CBO}$ ('Centraal Begeleidingsorgaan') [3], the screening cell set must answer to certain requirements such as the inclusion of at least one cell with homozygous expression of the Fy ${ }^{\mathrm{a}}, \mathrm{Fy}^{\mathrm{b}}$ (Duffy antigens), $\mathrm{Jk}^{\mathrm{a}}, \mathrm{Jk}^{\mathrm{b}}$ (Kidd antigens), $\mathrm{S}$ and $\mathrm{s}$ antigens (MNSs antigens) and heterozygous expression for the $\mathrm{K}$ (Kell) antigen $[4,5]$. If the antibody screen is negative, it can be predicted that more than $99 \%[2,6]$ of the RBC units electronically matched for $\mathrm{ABO}$ groups will be compatible in the crossmatch (XM) test [7]. A positive antibody detection test is followed by the determination of the antibody specificity and the assessment of its clinical significance. An identification panel must contain RBC from group $\mathrm{O}$ donors with at least two phenotypes lacking and 
at least two phenotypes expressing the corresponding antigen $\left(\mathrm{K}, \mathrm{k}, \mathrm{Jk}^{\mathrm{a}}, \mathrm{Jk}^{\mathrm{b}}, \mathrm{S}, \mathrm{s}, \mathrm{Fy}^{\mathrm{a}}\right.$ and $\left.\mathrm{Fy}^{\mathrm{b}}\right)[3,5]$.

Several studies already addressed the comparison of commercial test cell panels for the detection of RBC alloantibodies. However, only few studies have focused on differences in identification of those RBC alloantibodies. Chang et al. [8], Roback et al. [9] and Taylor et al. [10] compared test cell panels form Bio-Rad and Grifols for RBC antibody identification. Garozzo et al. [11] compared results with test cell panels from OCD with those from Immucor. Sawierucha et al. [12] compared Bio-Rad with OCD. Cid et al. [13] compared, as in our study, the cell panels from Bio-Rad, Grifols and OCD. The aim of our study was the comparison of three test cell panels for the identification of irregular RBC alloantibodies; Ortho RESOLVE $^{\circledR}$ panel C from Ortho BioVue ${ }^{\circledR}$ System, IDDiaPanel and ID-DiaPanel P from Bio-Rad and Identisera Diana and Identisera Diana P from Grifols.

\section{Main text \\ Materials and methods \\ Study design}

The main objective was to determine the performance of three test cell panels in identifting clinically relevant antibodies. Concordance rates were calculated according to the CLSI (Clinical \& Laboratory Standards Institute) guideline [14].

\section{Samples}

Samples $(n=44)$ for this study were collected from August 2016 until January 2018 and include ethylenediamine-tetraacetic acid (EDTA) plasma or serum from pre-transfusion testing with a positive screening result (OCD: $n=33$, Bio-Rad: $n=11$ ). Screening testing was done with corresponding 11-cell identification panel from OCD or Bio-Rad, using untreated and papaintreated RBC. Within 5 days after specimen collection or after being stored in a frozen state by $-20^{\circ} \mathrm{C}$, the samples were also tested with the remaining methods (OCD/ Bio-Rad and/or Grifols), if possible according to the available sample volume.

\section{Reagents}

Ortho BioVue System Poly Cassettes and Bio-Rad IDCards "LISS-Coombs" are comprised of six columns, while Grifols DG Gel Cards are eight column gel cards. Each microtube contains a wide reaction chamber in the upper part and an anti-human globulin (AHG) in the lower part. Cards from Ortho include a glass microbead matrix while cards from Bio-Rad and Grifols consist of a cross-linked gel (Sephadex) for the separation of agglutinated RBC. Additionally for the Ortho system, Ortho BLISS (a low ionic strength solution (LISS) designed to provide optimal ionic strength for antibody uptake) is to be added. All three systems also have 'Neutral Cards' which contain neutral gel suspension to perform saline and enzyme techniques (Ortho BioVue System Neutral Cassettes from OCD, $\mathrm{NaCl}$ enzyme test and cold agglutinins cards from Bio-Rad and DG Gel Neutral cards from Grifols). The following sets of reagent $\mathrm{RBC}$ were used: 3-5\% resolve C (OCD), 0.8\% ID-Diapanel 1-1 (BioRad) and $0.8 \%$ Identisera Diana (Grifols).

\section{Principle of procedure}

All three methods use the column agglutination technique. Agglutinated RBC are trapped in the gel or glass beads in the presence of irregular antibodies. According to the reaction pattern and the antigen configuration (displayed on an antigen table), the antibody present can be identified. In all samples, an autocontrol (AT; method testing the patient's own red cells) must be included to make a difference between auto- and alloantibodies [15-18].

The Grifols analyses were performed automatically (Erythra ${ }^{\circledR}$, Grifols) while the analyses by the other two methods were completed manually. Qualified laboratory technologists performed all tests in strict adherence to the manufacturer's instructions. All reactions were read carefully with the aid of an illuminated box by at least two individuals.

\section{Statistical analysis}

All statistical analyses were conducted using the Microscoft Excel + Analyse-it ${ }^{\circledR}$ software for Windows 10 (Analyse-it, Leeds, United Kingdom). Concordant results were measured and Cohen's kappa coefficient $(\mathrm{k})$ was assessed to compare the ability to detect RBC alloantibodies by the three methods.

\section{Results}

Out of 44 samples, 21 were investigated with all three methods. 23 samples were investigated with only two methods because of insufficient sample volume; seven samples with Bio-Rad and Grifols, and 16 samples with OCD and Grifols reagents (Additional file 1: Figure S1). In 38 samples at least one alloantibody was identified. An identical identification was found in 33 out of 38 samples. In four samples additional alloantibodies were found by a certain method; in two samples (tested with all three methods) an additional anti-D (Rhesus antigen), anti-Lu ${ }^{\mathrm{a}}$ (Lutheran antigen) and anti-C (Rhesus antigen) were discovered by Bio-Rad and Grifols (Table 1; sample $C, D$ ) and in two samples (tested with only OCD and Grifols) an additional anti-D was found by Grifols (Table 1; sample F, G). In those last two samples however, enzyme treated cells were necessary for the detection of 
Table 1 Overview of discordant/inconclusive results

\begin{tabular}{|c|c|c|c|c|c|}
\hline & Screening & Identification & Identification & Identification & Conclusion \\
\hline & method & Bio-Rad & $O C D$ & Grifols & Conciusion \\
\hline A & OCD & anti-Kp $p^{a}$ & negaiive ${ }^{(i)}$ & anti-Kp ${ }^{2(2)}$ & Inconclusive \\
\hline B & $\mathrm{OCD}$ & $\begin{array}{l}\text { anti-D } \\
\text { anti-E } E^{(2)}\end{array}$ & $\operatorname{anti-D}^{(3)}$ & $\begin{array}{c}\text { anti-D } \\
\text { anti- } \mathrm{E}^{(2)}\end{array}$ & Inconclusive \\
\hline $\mathrm{C}$ & OCD & $\begin{array}{c}\text { anti-D } \\
\text { anti-Lu }^{\text {a }}\end{array}$ & negative & $\begin{array}{c}\text { anti-D } \\
\text { anti-Lu }\end{array}$ & Discordant \\
\hline D & $\mathrm{OCD}$ & $\begin{array}{l}\text { anti-D } \\
\text { anti-C }\end{array}$ & anti-D & $\begin{array}{l}\text { anti-D } \\
\text { anti-C }\end{array}$ & Discordant \\
\hline $\mathrm{E}$ & Bio-Rad & anti-D & & $\operatorname{anti}^{-1} \mathrm{D}^{(3)}$ & Inconclusive \\
\hline $\mathrm{F}$ & OCD & & anti-C $\mathrm{C}^{(2)}$ & $\begin{array}{l}\text { anti-C }{ }^{(2)} \\
\text { anti-D }\end{array}$ & Discordant \\
\hline G & $\mathrm{OCD}$ & & anti-N & $\begin{array}{c}\text { anti-N } \\
\text { anti-D }^{(2)}\end{array}$ & Discordant \\
\hline $\mathrm{H}$ & OCD & & $\begin{array}{l}\text { aspecific reactions } \\
\text { (AT-) }\end{array}$ & negative (AT-) & Discordant \\
\hline
\end{tabular}

\begin{tabular}{|c|c|c|c|}
\hline \multirow{2}{*}{ Concordant results / } & \multicolumn{2}{|c|}{$19 / 21(91 \%) / \kappa=0.86$} & \\
\hline & & \multicolumn{2}{|c|}{$32 / 37(87 \%) / \kappa=00.82$} \\
\hline \multirow[t]{2}{*}{ Cohen' s kappa (к) } & $28 / 28(100 \%) / \kappa=1.00$ & & $28 / 28(100 \%) / \kappa=1.00$ \\
\hline & & $19 / 21(91 \%)$ & \\
\hline
\end{tabular}

\footnotetext{
(1) The antigen was not present in this test system

(2) Reaction only seen in enzyme-treated cells

(3) No possibility of using enzyme-treated cells because of insufficient sample volume
}

the additional antibodies. In one of the remaining samples, anti-Kp $\mathrm{p}^{\mathrm{a}}$ was not identified by OCD as $\mathrm{Kp}^{\mathrm{a}}$ was not present in the test system (Table 1; sample A). Results of two other samples were considered inconclusive because of insufficient sample volume (Table 1; sample B, E). An overview of these results is shown in Table 1.

Overall, the use of the described panels enabled the identification of 54 antibodies. The most frequently identified antibodies were anti-D (24.1\%) and anti-E (16.7\%), followed by anti-C (9.3\%) and anti-c $(9.3 \%)$. Table 2 reports the antibody specificities.

Six samples showed unexplained reactions in all methods used; nonspecific agglutination (reaction in only a few cells of the panels used), pan agglutination (positivity in all the cells of the panels used) or no reaction in any cell. One sample showed unexplained reactions with one method and a negative result with the other method and was therefore considered discordant (Table 1; sample H). In these six samples, three samples showed a positive AT result and three samples a negative result.

In addition to finding the antibody specificity in the samples, the presence of underlying antibodies with possible clinical significance must be excluded. Applying the rules defined by the $\mathrm{BSH}$ guidelines [3], underlying
Table 2 Overview of the antibody specificities

\begin{tabular}{|c|c|c|c|c|}
\hline Specificity & n (\%) & n (Bio-Rad) & n (OCD) & n (Grifols) \\
\hline anti-D & $13(24.1)$ & 8 & 7 & 13 \\
\hline anti-E & $9(16.7)$ & 7 & $7^{(1)}$ & $8^{(2)}$ \\
\hline anti-C & $5(9.3)$ & 3 & 3 & 5 \\
\hline anti-c & $5(9.3)$ & 4 & 4 & 5 \\
\hline anti-K & $4(7.4)$ & 2 & 3 & 4 \\
\hline anti-Fy ${ }^{a}$ & $4(7.4)$ & 1 & 4 & 4 \\
\hline anti-M & $3(5.6)$ & 2 & 2 & 3 \\
\hline anti-Le ${ }^{a}$ & $3(5.6)$ & 2 & 3 & 3 \\
\hline anti-Jk ${ }^{a}$ & $2(3.7)$ & 1 & 2 & 2 \\
\hline anti-Cw & $1(1.9)$ & 1 & 1 & 1 \\
\hline anti-Kp $p^{a}$ & $1(1.9)$ & 1 & n.t. ${ }^{(3)}$ & 1 \\
\hline anti-Lu ${ }^{a}$ & $1(1.9)$ & 1 & 0 & 1 \\
\hline anti-N & $1(1.9)$ & 0 & 1 & 1 \\
\hline anti-S & $1(1.9)$ & 0 & 1 & 1 \\
\hline anti-s & $1(1.9)$ & 1 & 1 & 1 \\
\hline Total & $54(100)$ & 34 & 39 & 53 \\
\hline
\end{tabular}

(1) Anti-E was not detected in one sample with OCD because of insufficient sample volume

(2) Anti-E was not detected in one sample with Grifols because of insufficient sample material

(3) The antigen $\mathrm{Kp}^{\mathrm{a}}$ was not present in this test system 
antibodies could not be excluded in 10 out of 28 samples tested with Bio-Rad (35.7\%), in 13 out of 37 samples tested with OCD (35.1\%) and in 14 out of 44 samples tested with Grifols (31.8\%). Those antibodies mostly belonged to blood group systems with significant clinical importance (Rhesus-, Kell-, Duffy-, Kidd- and MNSblood group systems).

\section{Discussion}

As in Chang et al. [8], Cid et al. [13] and Garozzo et al. [11], the most frequently identified antibodies were antiD (24.1\%), in direct relationship with antenatal prophylaxis against haemolytic disease of the newborn, and anti-E (16.7\%). Anti-K represented only $7.4 \%$ in our study while a greater percentage was described in Roback et al. [9] and Tayler et al. [10]. The concordance rate between Bio-Rad and Grifols is $100 \%$, between Bio-Rad and OCD 91\%, between OCD and Grifols $87 \%$ and between all three methods $91 \%$. These are similar percentages compared to the described articles above (Table 3).

Bio-Rad identified three additional antibodies in comparison with OCD (an anti-D, anti-Lua and anti-C), and Grifols identified five additional antibodies in comparison with OCD (an anti- Lua, anti-C, and three times antiD). It should be noted that anti-C can be missed when anti-D is present simultaneously and when the heterozygous cell for the antigen $\mathrm{C}$ (i.e. Cc) is not positive. This is because the homozygous cells for the antigen $\mathrm{C}$ (i.e. CC) overlap those with antigen D. The Bio-Rad, OCD and Grifols identification panels showed unexplained reactions in six samples. In three of those samples the AT was positive, suggesting the presence of autoantibodies [3, 19]. In the other three samples, the presence of a private antigen was not excluded. As far as the specificity of the antibodies, no equal identification rate was obtained with the three methods: the most antibodies were detected with Grifols and Bio-Rad, although sometimes the use of enzyme treated cells was necessary for the identification of the additionally discovered antibodies. The glass card method seems to be comparable to the gel card method in RBC antibody screening, although in stored samples, antibodies were more frequently detected with the gel card system.

The exclusion of underlying antibodies was not possible in a similar percentage of samples with all three methods. So it is important to recognize the limitations of the panel in use. A single panel may not permit identification of some common combinations of antibodies. A selection of two different panels increases the probability of being able to identify a mixture of antibodies. Additional techniques, for example the use of a panel of enzyme treated cells, can also be helpful in antibody identification and is strongly recommended for antibody identification, particularly when an antibody is weakly reactive with the antiglobulin technique, or when a mixture of antibodies is present [3]. We examined if there was a method that gave an advantage in the identification of the antibody as to the absence of additional nonspecific reactions making identification more difficult, the unnecessity of using additional techniques like enzyme treated panels and the positivity of both homozygous and heterozygous cells. Each method has a comparable degree of 'difficulties' concluding that there is no manifest advantage for one particular method in case of facilitation of antibody identification.

Table 3 Overview literature

\begin{tabular}{lllc}
\hline & Test cell panels & $\begin{array}{l}\text { IAGT identification no. of samples/ } \\
\text { concordant results }\end{array}$ & $\begin{array}{l}\text { Concordance } \\
\text { rate (\%) }\end{array}$ \\
\hline Taylor et al. [10] & Bio-Rad vs Grifols & $361 / 328$ & 90.86 \\
Cid et al. [13] & Bio-Rad vs Grifols & $26 / 25$ & 96.15 \\
& OCD vs Grifols & $26 / 24$ & 92.31 \\
& Bio-Rad vs OCD & $26 / 23$ & 88.46 \\
& Bio-Rad vs OCD vs Grifols & $26 / 23$ & 88.46 \\
Garozzo et al. [11] & OCD vs Immucor & $78 / 74$ & 94.87 \\
Chang et al. [8] & Bio-Rad vs Grifols & $51 / 50$ & 98.04 \\
Roback et al. [9] & Bio-Rad vs Grifols & $759 / 759$ & 98.68 \\
Sawierucha et al. [12] & Bio-Rad vs OCD & $165 / 226$ & 73.00 \\
Blomme et al. (2019) & Bio-Rad vs Grifols & $28 / 28$ & 100.00 \\
& OCD vs Grifols & $32 / 37$ & 86.49 \\
& Bio-Rad vs OCD & $19 / 21$ & 90.48 \\
\hline
\end{tabular}




\section{Conclusion}

Three test cell panels for identification of irregular RBC antibodies were compared: Autovue ${ }^{\circledR}$ Innova (Ortho Clinical Diagnostics (OCD), Milan, Italy), ID-GelStation (Bio-Rad Laboratories, CA, USA) and Erytra ${ }^{\circledR}$ (Grifols, Barcelona, Spain). The resulting antibody identifications showed subtle differences between the three methods, with the gel card system (Bio-Rad and Grifols) being superior to the glass card system (Ortho) for analyzing stored samples. However, no manifest advantage for a particular method in case of facilitation of antibody identification was found. In conclusion, all three systems were considered reliable and safe for routine testing in the immunohematology laboratory.

\section{Limitations}

Only one manufacturing lot number of a test cell panel was tested for each firm, which can also explain certain differences. In our study, there is also no adjustment for the fact that the expression of $\mathrm{RBC}$ antigens on each reagent cell in a panel from one manufacturer is not the same as the expression on the RBC's in a panel from another manufacturer.

\section{Supplementary information}

Supplementary information accompanies this paper at https://doi. org/10.1186/s13104-020-04974-x.

Additional file 1: Figure S1. Overview tested samples.

\begin{abstract}
Abbreviations
AT: Autocontrol; BSH: British Society of Haematology; CBO:'Centraal Begeleidingsorgaan' (The Netherlands); CLSI: Clinical \& Laboratory Standards Institute; D, C, C, E, C ${ }^{W}$ : Rhesus antigens; EDTA: Ethylenediaminetetraacetic acid; Fy', Fy ${ }^{\text {b: }}$ Duffy antigens; HDFN: Hemolytic disease of the fetus and newborn; IAT:

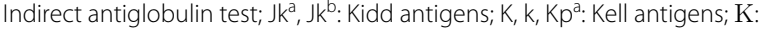
Cohens's kappa coefficient; Le $e^{\text {a }}$ Lewis antigen; LISS: Low ionic strength solution; Lu': Lutheran antigen; OCD: Ortho Clinical Diagnostics; RBC: Red blood cell.
\end{abstract}

\section{Acknowledgements \\ None.}

\section{Authors' contributions}

EV designed the research study and contributed essential reagents and tools. EDM assisted in analyzing the data. SB performed the research, analyzed the data and wrote the paper. All authors read and approved the final manuscript.

\section{Funding}

This publication was made possible through funding support of the KU Leuven Fund for Fair Open Access.

\section{Availability of data and materials}

The datasets used and/or analyzed during the current study are available from the corresponding author on reasonable request.

\section{Ethics approval and consent to participate}

The study was approved by the Ethics Committee at AZ Delta Hospital in context of an analyzer validation. No consent from study participants was required given that it is a retrospective study in the context of an analyzer validation. No ethical issues arose during the study as all the data remained anonymous with no identifying personal data.

\section{Consent for publication}

Not applicable.

\section{Competing interests}

The authors declare that they have no competing interests.

\section{Author details}

${ }^{1}$ Clinical Department of Laboratory Medicine, University Hospitals, Herestraat, 493000 Leuven, Belgium. ${ }^{2}$ Clinical Department of Laboratory Medicine, University Hospitals, St. Pietersnieuwstraat 33, 9000 Ghent, Belgium. ${ }^{3}$ Clinical Departments of Laboratory Medicine, AZ Delta Hospital, Ardooisesteenweg 276, 8800 Roeselare, Belgium.

Received: 30 December 2019 Accepted: 24 February 2020 Published online: 04 March 2020

\section{References}

1. Alavi-Moghaddam M, Bardeh M, Alimohammadi H, Emami H, HosseiniZijoud SM. Blood transfusion practice before and after implementation of type and screen protocol in emergency department of a university affiliated hospital in Iran. Emerg Med Int. 2014. https://doi. org/10.1155/2014/316463.

2. Boral LI, Henry JB. The type and screen: a safe alternative and supplement in selected surgical procedures. Transfusion. 1977;17:163-8.

3. Milkins C, Berryman J, Cantwell C, Elliott C, Haggas R, Jones J, Rowley M, Williams M, Win N. Guidelines for pre-transfusion compatibility procedures in blood transfusion laboratories (British Committee for Standards in Haematology). Transfus Med. 2013;23:3-35.

4. Garratty G. How concerned should we be about missing antibodies to low incidence antigens? Transfusion. 2003;47(7):844-7.

5. Knowles SM, Milkins CE, Chapmanyand JF, Scott M. The United Kingdom National External Quality Assessment Scheme (blood transfusion laboratory practice): tends in proficiency and practice between 1985 and 2000. Transfus Med. 2002;12:11-23.

6. Powers A, Chandrashekar S, Mohammed M. Identification and evaluation of false-negative antibody screens. Transfusion. 2010;50:617-21.

7. Orlando N, Bianchi M, Giovanna C, Valentini VM, Maresca M, Massini G, Putzulu R, Zini G, Teofili L. Red cell alloantibody screening: comparative analysis of three different technologies. Transfus Med Hemother. 2018;45:179-83.

8. Chang C, Brown M, Davies L, Pointon L, Brown R, Barker D. Evaluation of Erytra ${ }^{\circledR}$ fully automated analyser for routine use in transfusion laboratoy. Transfus Med. 2013;24:33-8.

9. Roback JD, Barclay S, Moulds JM, Denomme GA. A multicenter study on the performance of a fully automated, walk-away high-throughput analyzer for pretransfusion testing in the US population. Transfusion. 2015:55:1522-8.

10. Taylor J, Hyare J, Stelfox P, Williams M, Lees R, Maley M. Multi-centre evaluation of pre-transfusional routine testing using 8-column format gel cards (DG Gel ${ }^{\circledR}$ ). Transfus Med. 2011;21:90-8.

11. Garozzo G, Licitra V, Criscione R, Comitini N, Noto C, Lomagno R, Ruta D, Spadola G, Zago V, Bonomo P. A comparison of two automated methods for the detection and identification of red blood cell alloantibodies. Blood Transfus. 2007:5:33-40.

12. Sawierucha J, Posset M, Hähnel V, Johnson CL, Hutchinson JA, Ahrens N. Comparison of two column agglutination tests for red blood cell antibody testing. PLOS ONE. 2018;13(12):e0210099.

13. Cid J, Nogue's N, Montero R, Hurtado M, Briega A, Parra R. Comparison of three microtube column agglutination systems for antibody screening: DG Gel, DiaMed-ID and Ortho BioVue. Transfus Med. 2006;16:131-6.

14. CLSI guideline, Clinical and Laboratory Standards Institute. CLSI document (EP12); 2018.

15. Bunker LB, Thomas $C L$, Geyer SJ. Optimizing pretransfusion antibody detection and identification: a parallel, blinded comparison of tube PEG, solid-phase, and automated methods. Transfusion. 2001;41:621-6. 
16. Molaro GL. L evoluzione tecnologica in immunoematologia eritrocitaria. Ligand Q. 1993;12:466-74.

17. Weisbach V, Kohnhäuser T, Zimmermann R, Ringwald J, Strasser E, Zingsem J, Eckstein R. Comparison of the performance of microtube column systems and solid-phase systems and the tube low-ionic-strength solution additive indirect antiglobulin test in the detection of red cell alloantibodies. Transfus Med. 2006;16:276-84.

18. Shin SY, Kwon KC, Koo SH, Park JW, Ko CS, Song JH, Sung JY. Evaluation of two automated instruments for pre-transfusion testing: autoVue Innova and Techno TwinStation. Korean J Lab Med. 2008;28:214-20.
19. Maley M, Bruce DG, Babb RG, Wells AW, Williams M. The incidence of red cell alloantibodies underlying panreactive warm autoantibodies. Immunohematology. 2005;21:122-5.

\section{Publisher's Note}

Springer Nature remains neutral with regard to jurisdictional claims in published maps and institutional affiliations.
Ready to submit your research? Choose BMC and benefit from:

- fast, convenient online submission

- thorough peer review by experienced researchers in your field

- rapid publication on acceptance

- support for research data, including large and complex data types

- gold Open Access which fosters wider collaboration and increased citations

- maximum visibility for your research: over $100 \mathrm{M}$ website views per year

At BMC, research is always in progress.

Learn more biomedcentral.com/submissions 